\title{
COVID-19 and acute kidney injury
}

\author{
Lale A. ERTUĞLU ${ }^{1}(I D)$ \\ Asiye $\operatorname{KANBAY}^{2}(\mathrm{ID})$ \\ Barış AFŞAR $^{3}$ (ID) \\ Rengin ELSÜRER \\ AFŞAR $^{3}$ (ID) \\ Mehmet $\operatorname{KANBAY}^{4}(\mathrm{ID})$
}

${ }^{1}$ Department of Internal Medicine, Koc University School of Medicine, Istanbul, Turkey

${ }^{1}$ Koç Üniversitesi Tıp Fakültesi, Iç Hastalıkları Anabilim Dalı, İstanbul, Türkiye

2 Department of Chest Diseases, Istanbul Medeniyet University School of Medicine, Istanbul, Turkey

2 Istanbul Medeniyet Üniversitesi Tıp Fakültesi, Göğüs Hastalıkları Anabilim Dalı, Istanbul, Türkiye

${ }^{3}$ Division of Nephrology, Department of Internal Medicine, Suleyman Demirel University School of Medicine, Isparta, Turkey

3 Süleyman Demirel Üniversitesi Tıp Fakültesi, iç Hastalıkları Anabilim Dalı, Nefroloji Bilim Dalı, Isparta, Türkiye

${ }^{4}$ Division of Nephrology, Department of Internal Medicine, Koc University School of Medicine, Istanbul, Turkey

${ }^{4}$ Koç Üniversitesi Tıp Fakültesi, lç Hastalıkları Anabilim Dalı, Nefroloji Bilim Dalı, İstanbul, Türkiye
Cite this article as: Ertuğlu LA, Kanbay A, Afşar B, Elsürer Afşar $R$, Kanbay M. COVID-19 and acute kidney injury. Tuberk Toraks 2020;68(4):407-418.

\section{Yazışma Adresi (Address for Correspondence)}

\section{Dr. Asiye KANBAY}

İstanbul Medeniyet Üniversitesi Tıp Fakültesi, Göğüs Hastalıkları Anabilim Dalı,

ISTANBUL - TÜRKIYE

e-mail: kanbaydr@yahoo.com
CCopyright 2020 by Tuberculosis and Thorax. Available on-line at www.tuberktoraks.org.com

\section{ABSTRACT}

\section{COVID-19 and acute kidney injury}

The Coronavirus disease 2019 (COVID-19) pandemic caused by severe acute respiratory syndrome-coronavirus-2 (SARS-CoV-2) started in December 2019 and has affected millions of lives worldwide, while many aspects of the illness are still unknown. Current data show that many hospitalized COVID-19 patients suffer from kidney damage, in the form of proteinuria, hematuria or acute kidney injury (AKI). AKI is especially prevalent among severe and critically ill COVID-19 patients and is a predictor of mortality. The pathophysiology of AKI in COVID-19 is unclear. Early reports of histopathologic examination from autopsied kidney tissue show SARS-CoV-2 viral particles in renal tubular cells and podocytes, suggesting direct viral infection, as well as findings of acute tubular necrosis, while rhabdomyolysis-associated AKI and glomerulopathies may also occur. As of today, only remdesivir has been authorized to treat COVID-19. Ongoing research investigates potential of anti-viral and anti-inflammatory agents along with safety and efficacy of commonly prescribed drugs such as renin-angiotensin-aldosterone system blockers. This review discusses the prevalence of $A K I$ and its association with outcome, while highlighting possible mechanisms of AKI and suggesting organ protective measures to prevent the development of kidney damage.

Key words: COVID-19; acute kidney injury; mortality 
ÖZ

\section{COVID-19 ve akut böbrek hasarı}

Coronavirüs hastalığı 2019 (COVID-19) Aralık 2019 tarihinden beri ağır solunum yolu hastalığına (SARS-CoV-2) neden olmaktadır. Şu ana kadar milyonun üzerinde insan hastalığa yakalanmış olmasına rağmen hastalığın etyopatogenezi tam bilinmemekte ve birçok organ tutulumu ile seyredebilmektedir. COVID-19'un hastalarda hematüri, proteinüri, akut böbrek hasarı gibi sorunlara $(A B H)$ neden olabildiği rapor edilmiştir. ABH özellikle yoğun bakım hastalarında daha sık olup mortalite ve morbidite ile ilişkili bulunmuştur. Ancak COVID-19'a bağ/ı ABH etyopatogenezi tam bilinmemektedir. SARS-CoV-2'ye bağlı ölen hastaların otopsi raporlarında virüsler böbrek tubul hücrelerinde saptandığından direkt olarak virüse bağlı hasar olduğu düşünülmektedir. Bununla birlikte rabdomyoliz, glomerulonefrit, akut tubuler nekroz tiplerinde de akut böbrek hasarı bildirilmiştir. Güncel bilgiler ışı̆̆ında henüz sadece Remdesevir'in tedavide etkili olduğu bilinmektedir. Bu derlemede COVID-19 hastalarında akut böbrek hasarı sıklı̆̆ı, tipleri ve nedenleri ve muhtemel tedavi modaliteleri tartışılmıştır.

Anahtar kelimeler: COVID-19; akut böbrek hasarı; mortalite

\section{INTRODUCTION}

In December 2019, a series of pneumonia cases caused by a novel severe acute respiratory syndrome coronavirus 2 (SARS-CoV-2) occurred in Wuhan, Hubei Province, China. The disease, now officially named coronavirus disease 2019 (COVID-19), rapidly spread from Wuhan to other cities worldwide. As of June $10^{\text {th }} 2020$, there are more than 7.500 .000 confirmed COVID-19 cases and 423.000 deaths worldwide (1), with an estimated mortality rate of $2.3 \%$ (2). COVID-19 primarily presents with fever, dry cough, dyspnea and diarrhea, although the presentation can range from asymptomatic infection to respiratory compromise with multi-organ failure and high mortality (3). While respiratory failure is the most dominant feature of severe disease, the sec- ond-most commonly affected organ by COVID-19 has been reported to be the kidney (4). In this review, we discuss the epidemiology and prognostic value of development of acute kidney injury (AKI) in COVID19, with an emphasis on possible pathophysiology and preventive methods that may guide clinical practice during this emerging crisis.

\section{Epidemiology of Acute Kidney Injury in COVID-19}

The prevalence of kidney injury among hospitalized COVID-19 cases varies vastly in each series, with a reported highest prevalence of $69 \%$ (5) (Table 1). Importantly, a meta-analysis of 3062 COVID-19 patients found a $25.5 \%$ incidence of abnormal renal function, defined as an increase in serum creatinine (6).

Table 1. Clinical characteristic of studies

\begin{tabular}{|c|c|c|c|c|c|c|}
\hline & Country & $\begin{array}{l}\text { Number } \\
\text { of patients }\end{array}$ & $\begin{array}{c}\text { Study } \\
\text { population }\end{array}$ & Percent of AKI & $\begin{array}{c}\text { Risk of mortality among } \\
\text { patients with AKI }\end{array}$ & $\begin{array}{l}\text { Kidney injury } \\
\text { assessment }\end{array}$ \\
\hline Aggarwal et al. (5) & US & 16 & Hospitalized & $69.0 \%$ & NA & KDIGO \\
\hline Cheng et al. (7) & China & 701 & Hospitalized & $5.1 \% \mathrm{AKI}$ & $\begin{array}{c}33.7 \% \text { in patients with } \\
\text { elevated baseline serum } \\
\text { creatinine }\end{array}$ & KDIGO \\
\hline Yang et al. (10) & China & 52 & Critically ill & $29 \%$ & $80 \%$ of $\mathrm{AKI}$ & KDIGO \\
\hline Diao et al. (9) & China & 85 & Hospitalized & $27 \%$ & NA & $\begin{array}{l}\text { A decline of eGFR } \\
\text { by at } \geq 30 \% \text { of the } \\
\text { baseline value on }\end{array}$ \\
\hline Li et al. (4) & China & 54 & Hospitalized & $70.7 \%$ & KDIGO & $\begin{array}{l}\text { eGFR }<90 \mathrm{~mL} / \mathrm{min} \\
\text { on admission }\end{array}$ \\
\hline Zhou et al. (13) & China & 191 & Hospitalized & $14.7 \%$ & $96.4 \%$ & KDIGO \\
\hline Chen et al. (14) & China & 274 & Hospitalized & $11.0 \%$ & $25.0 \%$ & KDIGO \\
\hline Pei et al. (8) & China & 333 & Hospitalized & $6.60 \%$ & $86.4 \%$ & KDIGO \\
\hline Pei et al. (8) & China & 333 & Hospitalized & $10.5 \%$ & $57.1 \%$ & Expanded criteria \\
\hline
\end{tabular}


Currently, the true incidence of AKI in hospitalized COVID-19 patients is not known. In a cohort of 701 in patients with COVID-19, the incidence of AKI was $5.1 \%$ (7). In another cohort of 467 , it was $4.7 \%$ (8). However, retrospective analysis of the early data from Wuhan suggested that $27 \%$ of 85 hospitalized COVID-19 cases developed AKI (9), in line with the results of the meta-analysis (6).

Regardless, all reports consistently observed higher incidence of AKI in critically ill patients. Very early data showed $29 \%$ of 52 critically ill Chinese patients developed AKI (10). In another study, $23 \%$ of patients admitted to ICU developed AKI, while none did in non-ICU care (11). More recently, a report from Bellevue Hospital Center in New York revealed that 44 out of 105 patients with COVID-19 in the ICUs had AKI, 40 of who required kidney replacement therapy (12). Another recent retrospective study from China reported kidney injury in $70 \%$ of severe and critically ill patients (4).

The incidence of AKI is also strikingly high in non-survivors. Two retrospective studies from Wuhan reported $\mathrm{AKI}$ in $50 \%$ (13) and 25\% (14) of 54 and 113 non-survivors, respectively. While AKI developed at a median of 15 days [13.0-19.5] after illness onset (13), earlier signs of kidney dysfunction were evident much earlier in the disease course. Remarkably, a high percentage of patients had signs of kidney dysfunction on hospital admission, including $65 \%$ to $44 \%$ with proteinuria, $44 \%$ to $27 \%$ with hematuria, $14 \%$ to $10 \%$ with increased serum creatinine $(7,8,15)$. Among 333 COVID-19 patients in China, 251 (75\%) presented with renal complications including proteinuria, hematuria and AKI. The study excluded patients with baseline CKD or suspected CKD who had one abnormal urine test in the 3 months before admission (8), strongly suggesting that the renal abnormalities found were related to COVID-19. Given that median duration from illness onset to admission was 9 to 10 days $(7,8)$, it is reasonable to interpret that the renal impairment starts even before hospital admission. However, most reports so far have come from China and information is still needed from other ethnicities and populations. Additionally, the evolving therapeutic approach may also potentially impact the epidemiology.

\section{Features of AKI}

Kidney injury due to COVID-19 presented as increased serum creatinine levels, proteinuria, hema- turia and $\mathrm{AKI}$, with some of the patient requiring renal replacement therapy (RRT) (8). Overall, AKI was defined according to the KDIGO criteria $(7,8,10,15-$ 17), while different definitions of kidney injury, including decreased eGFR (4) and extended criteria (8), were also used. AKI Stage 1 was seen in $18 \%$ and stage 2 was seen in $32 \%$, while $50 \%$ of the patients reached stage 3 (8). High rates of proteinuria and hematuria have been found in hospitalized COVID19 patients. In a cohort of 333 admitted COVID-19 patients, proteinuria and hematuria were demonstrated in $65.5 \%$ and $41.7 \%$ of the patients respectively (8), and were associated with mortality in intensive care unit (ICU) patients (18). Renal involvement was also evident on $\mathrm{CT}$ imaging; the mean $\mathrm{CT}$ value and CT texture analysis parameters were significantly lower in COVID-19 patients than in healthy controls who had no kidney disease (15).

Various renal pathologic changes were observed in COVID-19 infected patients. The histopathologic analysis of six autopsies of patients with COVID-19 with renal involvement showed viral particles in proximal renal tubules and podocytes, with varying degrees of acute tubular necrosis and lymphocytic infiltration (9) (Figure 1). Regardless, it should be noted that the key findings in the pathologic examination revealed prominent proximal acute tubule injury manifesting as vacuolar degeneration, loss of brush border, aggregates of red blood cells without platelet or fibrin plugs and occasionally even frank necrosis, which is consistent with acute tubular necrosis (ATN) (19). Hence, the dominant form of AKI in SARS-CoV-2 infection appears to be intrarenal AKI. Of note, pigmented casts with high levels of creatine kinase, findings consistent with rhabdomyolysis were also found among COVID-19 non-survivors (19), while several cases of collapsing glomerulopathy and crescentic proliferative glomerulonephritis have also been reported $(20,21)$. Although renal involvement was strongly associated with higher mortality, the high rate of resolution of renal manifestations in survivors also supports that ATN may be the predominant renal insult (8).

\section{Outcome of AKI in COVID-19 Patients}

AKI has been consistently associated with increased mortality rates in COVID-19 patients. In a study including 193 COVID-19 patients, the mortality rates of patients who developed AKI was 5.3 times higher than those without AKI (15). A 701 inpatient cohort 
- Clusters of viral particles were found in proximal renal tubule and podocytes

- Anti- SARS-CoV-2 antibody staining was positive in the tubules

- Macrophage infiltrates and complement deposits were seen in the tubulointerstitium

- ACE2 expression was increased in areas of acute tubular injury

- Pigmented casts with high levels of creatinine phosphokinase were found, suggested rhabdomyolysis associated AKI

- Cases of collapsing glomerulopathy and crescentic proliferative glomerulonephritis have been reported

- ACE2 RNA was expressed nearly 100-fold more in the kidney than in the lungs

- ACE2 and TMPRSS, two genes crucial for viral entry, were highly coexpressed in proximal tubular cells and podocytes

Figure 1. Healthy kidney tissue expression of viral entry receptors ACE2 and TMPRSS2 and histo-pathological findings during COVID-19 infection.

ACE2 and TMPRSS are highly expressed in kidney tissue, especially in proximal tubules. This allows corona viruses to attach to tubular cells and to infect renal tissue. Various histopathological findings were observed in COVID-19 patient kidneys. Both direct involvement by the virus and immune system activation play a role for the pathologic findings.

ACE 2: Angiotensin converting enzyme 2, TMPRSS2: Transmembrane Serine Protease 2.

study in Wuhan demonstrated that AKI over stage 2 was independently associated with in-hospital death (7). The mortality risk was more than 4 times higher among patients with stage $3 \mathrm{AKI}$ (hazard ratio 9.81, 95\% Cl: 5.46-17.65) (7). The dose-dependent relationship between AKI stages and death was also supported by other cohorts (8). In another report, 32 out of 33 COVID-19 patients who developed AKI did not survive (13).

Kidney dysfunction evident by proteinuria and hematuria without fulfilling AKI criteria may also predict outcomes. The incidences of proteinuria and hematuria in critically ill patients were almost two-fold higher than in moderately ill patients ( $81 \%$ versus $44 \%$ for proteinuria, $69 \%$ versus 33\% for hematuria) (8). Among 333 COVID-19 patients, the mortality rate in patients with renal involvement, including hematuria, proteinuria and $\mathrm{AKI}$, was more than 9-fold higher than in those without renal involvement $(11.2 \%$ versus $1.2 \%$, respectively) (8). Comparably, the peak BUN and creatinine levels of severe cases, including the deceased cases, were significantly higher than those of non-severe COVID-19 cases and non-
COVID pneumonia (15). The median creatinine level on admission in non-survivors was significantly higher than in survivors, despite remaining in the normal range (87 versus $68 \mu \mathrm{mol} / \mathrm{L})(16)$.

Kidney injury is also commonly seen with cardiac injury, possibly since both are predictors of severe illness. The reported incidence of AKI in patients with cardiac injury was more than 26 -fold higher than in those without cardiac injury ( $8.5 \%$ vs. $0.3 \%$ ) (17).

In line with the high incidence of AKI, RRT is the second most common organ support needed in critically ill COVID-19 patients, only after ventilator support. According to a report from China, $17 \%$ of critically ill patients (9 out of 52) were treated with RRT (10). In another report from New York, 38\% of COVID-19 patients in the ICU (40 out of 105) required RRT (12).

According to the UK ICNARC report (1 May 2020), $23 \%$ of critically ill COVID-19 patients (1163 of 5139) required renal support. Of the patients who had renal support, almost $75 \%$ died in critical care. Of note, only $5.3 \%$ of the patients who required RRT 
had severe renal disease prior to admission, suggesting that baseline chronic kidney disease (CKD) played only a minor role in the need for RRT (ICNARC COVID-19 report 2020-05-01.pdf at https://www. icnarc.org/Our-Audit/Audits/Cmp/Reports; accessed May 3, 2020).

Similar to the ICNARC report, survival rates of patients who required RRT were dramatically low in small reports as well. In one study, 8 out of 9 patients who received RRT did not survive (7), while in another, 10 out of 10 patients did not survive (13).

Based on the current evidence, both the development of renal dysfunction and requirement of RRT are predictors of strikingly poor prognosis and can be used to assess possible outcome in the clinical setting. Nevertheless, according to one study, remission of kidney injury is common among survivors: $68 \%$ of patients with proteinuria (111 of 162) and $44 \%$ of patients with hematuria (44 of 102) were reported as negative after remission of COVID-19 (8). Furthermore, $18 \%$ of patients with AKI (4 of 22) had complete recovery of kidney function at follow-up, with a mean recovery time of 6 days (8). Critical illness was a negative risk factor for recovery from $\mathrm{AKI}$, while age $\geq 60$ years, ACEI/ARB treatment before admission and AKI were negative risk factors for hematuria remission (8). Larger cohort studies are needed for better understanding of renal prognosis in COVID-19 related AKI.

\section{Pathophysiology of AKI in COVID-19 Patients}

SARS-CoV-2 uses angiotensin converting enzyme 2 (ACE2) as receptor for cellular entry. ACE2 is abundant lungs. The viral spike $(S)$ protein directly binds to ACE2, while the endocytosis and membrane fusion processes are allowed by cellular transmembrane serine protease 2 (TMPRSS2) (22). Once inside the cell, the synthesis of viral polyproteins for the replicase-transcriptase complex ensues. Following RNA and structural protein synthesis, new viral particles are assembled and released $(22,23)$.

Recently, postmortem histopathological analysis of 26 COVID-19 patients revealed direct evidence of invasion renal tissue by SARS-CoV-2. Electron microscopy revealed clusters of coronavirus particles in renal tubular epithelium and podocytes, whereas there was positive immune staining with anti-SARSCoV nucleoprotein antibody in tubules (19). In line with the previous data, a preprinted report of kidney immunohistochemistry from six deceased COVID-19 cases found that SARS-CoV-2 NP antigen accumulated in kidney tubules (9), while virus-like particles were also visible by electron microscopy. Moreover, infiltrates of CD68+ macrophages and complement C5b-9 deposits were visualized in the tubulointerstitium (9).

Interestingly, ACE2 expression was increased in proximal tubular cells, especially in areas of acute tubular injury within COVID-19 infected kidneys (19). Indeed, ACE2 is highly expressed in the kidney. According to the Pub Med genome database, ACE2 RNA expression in the kidney is nearly 100 -fold higher than in lung $(7,24)$, while TMPRSS2 expression is comparable with lung (25) (https://www.ncbi.nlm. nih.gov/gene/7113) (https://www.ncbi.nlm.nih.gov/ gene/?term $=59272 \#)$. Considering that the co expression of ACE2 and TMPRSS2 is essential for SARSCoV-2 entry, a recent single-cell RNA sequencing analysis investigated the expression of ACE2 and TMPRSS2 (Transmembrane Serine Protease) genes in normal kidney samples. The analysis revealed high co expression of ACE2 and TMPRSS2 genes in podocytes and proximal tubule cells (26), which may explain the distribution of viral particles in autopsy tissue.

These findings suggest that proximal tubular cells and podocytes are host cells for SARS-CoV-2. Given that podocyte injury manifests as proteinuria, it is plausible to link the high incidence of proteinuria in hospitalized COVID-19 patients to cytopathic effects of SARS-CoV-2 on podocytes. Thus, available data suggest that SARS-CoV-2 may directly infect renal tubular cells and podocytes and initiate macrophage infiltration and complement deposition to amplify tubular damage.

Secondly, the inflammatory process following lung injury could damage the kidney. The release of large amounts of cytokines and inflammatory mediators, known as the cytokine release syndrome (CRS), could damage renal tubular cells, which in turn would amplify the inflammatory response and rapidly lead to multi organ failure. CRS is a complication of sepsis due to viral, bacterial and fungal infections (27) and has been characterized in COVID-19 consistently since the early reports of the disease $(11,28,29)$. In the setting of CRS, AKI may develop due to systemic endothelial injury, increased vascular permeability, intravascular volume depletion and intrarenal inflammation (30). On the other hand, kidney injury could 
further aggravate the inflammatory milieu and contribute to the high mortality risk seen in patients who suffer AKI. To address the possible role of CRS in the development of multi-organ failure in severe COVID19 patients, several therapeutic agents targeting major inflammatory mediators are under investigation, as discussed below.

Thirdly, a minority of cases could suffer from glomerulopathies following viral infection. The occurrence of glomerulopathies, including focal segmental glomerulosclerosis (FSGS) and membranous glomerulopathy, following viral infections (such as EBV, HIV, hepatitis $B$ and $C$, influenza) is a well-known phenomenon. Indeed, there have been two reports of collapsing glomerulopathy, a variant of FSGS, diagnosed with renal biopsy in COVID-19 positive African American patients. Of note, one of the patients presented with oliguria following the resolution of influenza-like symptoms, while the other patient suffered from severe lung manifestation (21, 31 ). It is known that $13 \%$ of African American individuals possess homozygous APOL1 risk alleles, predisposing them to kidney disease. These reports raise the suspicion of APOL1-related kidney disease in African American patients triggered by COVID-19 (31), in a similar manner that HIV triggers HIVassociated nephropathy in these patients (32).

Drug -or hyperventilation- induced rhabdomyolysis, apparent from high levels of creatine kinase, may also contribute to COVID-19-induced kidney damage. In the postmortem renal tissue analysis of COVID-19 patients, pigment casts were observed in 3 out of 26 patients (19).

\section{Treatments and Their Renal Implications}

Up to recently, there was no pharmacologic agent approved for COVID-19. Treatment strategies include antivirals to block viral entry or inhibit viral replication inside cells, anti-inflammatory agents to attenuate overactive inflammatory responses, anticoagulants to prevent thromboembolic complications and organ support in case of organ failure.

\section{Drugs Targeting SARS-CoV-2}

Remdesivir, a nucleotide analogue pro drug was recently (May 1, 2020), authorized for emergency use in COVID-19 by the US FDA (33). Remdesivir has a potent in vitro antiviral activity against SARS-CoV-2 resulting from inhibition of RNA-dependent RNA polymerase (22). Recent encouraging results have been observed in 61 COVID-19 patients treated with at least one dose of remdesivir and multiple clinical trials to evaluate the safety and efficacy of remdesivir are underway or have been recently concluded (clinicaltrials.gov NCT04365725, NCT04292899, NCT04292730, NCT04323761, NCT04302766, NCT04330690). Results from NCT04280705 and NCT04292899 were the basis for the FDA decision. While no dose adjustments are recommended at this time, the formulation contains a cyclodextrin vehicle, which raises the concern of potential accumulation in renal impairment. Therefore, use should be avoided in patients with eGFR $<30 \mathrm{~mL} / \mathrm{min}$ (34).

Lopinavir/ritonavir, an oral combination agent for HIV treatment, is another antiviral agent currently being investigated for the treatment of COVID-19 and has been widely used for COVID-19 as off-label treatment (35), although a recent open-label randomized clinical trial in 199 patients did not find benefit (36). It does not need dosage adjustment for renal impairment. Similarly, darunavir/cobicistat, another antiviral investigated for COVID-19 treatment, does not need dose adjustment (34).

Chloroquine and hydroxychloroquine are the most commonly used drugs in the literature since the start of the COVID-19 pandemic (35), although there is insufficient data to support their efficacy. Via a poorly understood mechanism, they appear to inhibit viral fusion and glycosylation of viral proteins and their activity against SARS-CoV-2 has been shown in vitro (22). However, convincing evidence for their clinical efficacy in the treatment of COVID-19 is lacking. A small series from China reported positive outcomes in patients treated with chloroquine (37), however, clinical trial design and outcomes data are not published in peer review journals, raising concern for the validity of the claims (22). Another open-label study of 36 COVID-19 patients claimed higher rates of virologic clearance in nasopharyngeal swabs but the study was limited by a small sample size and removal of 6 patients from the hydroxychloroquine group due to critical illness or intolerance of medications $(22,38)$. Later small studies observed no efficacy of hydroxychloroquine in COVID-19 and potential toxicity in critically ill patients $(39,40)$. From a renal standpoint, hydroxychloroquine/chloroquine does not have known renal side effects and do not need dosage adjustment for short time use in renal impairment. Nevertheless, both drugs have rare, serious side 
effects including QTc prolongation and retinopathy (22) and should be used with caution.

Since binding of the viral S protein to human ACE2 receptors are essential for viral entry into cells, human recombinant soluble ACE2 (hrsACE2) can potentially decrease viral infectivity by acting as a decoy receptor. A recent study on engineered human blood vessel and human kidney tissue have shown that hrsACE2 significantly blocks SARS-CoV-2 infectivity, suggesting potential therapeutic value for early stages of the infection (41). Previously, a pilot phase II trial found thatGSK2586881, a recombinant human ACE2 (rhACE2), was safe in patients with ARDS (42, 43), which may be a promising option for future trials.

\section{Drugs Targeting Inflammation}

Given that the clinical presentation of COVID-19 ranges from asymptomatic to multi-organ failure; therapies may be focused on preventing disease progression and systemic decompensation. Suppressing the inflammatory storm induced by COVID-19 is a potential way to prevent deterioration and development of multi-organ failure. In this light, Interleukin-6 (IL-6), a major pro-inflammatory mediator in the development of cardio-renal syndrome (CRS), has been suggested as a therapeutic target for severely and critically ill COVID-19 patients. Serum IL-6 levels were significantly higher in critically ill COVID19 patients than in severe patients. In addition, 35 out of 47 COVID-19 patients had IL-6 levels above the normal range (4). Preliminary data regarding the use of tocilizumab, a humanized anti-IL-6 receptor antibody that is successfully being used in other types of cytokine storm (44) in severe COVID-19 suggest that IL-6 blockade may reduce mortality and the need for mechanical ventilation if administered early (45-47), while no data on kidney outcomes are available yet. Currently, 21 ongoing clinical trials investigate tocilizumab for the treatment of COVID-19 patients (clinicaltrials.gov NCT04332094 NCT04317092 NCT04332913 NCT04345445 NCT04361032 NCT04359667 NCT04335071 NCT04331795 NCT04346355 NCT04320615 NCT04372186 NCT04363736 NCT04363853 NCT04356937 NCT04306705 NCT04310228 NCT04370834 NCT04315480 NCT04333914 NCT04361552 NCT04331808). If effective, tocilizumab may decrease kidney damage due to severe COVID-19.
Although corticosteroids have been tried in the rationale that they may attenuate lung inflammation and decreased the incidence of acute respiratory distress syndrome (ARDS), potential harms including decreased viral clearance and increased secondary infection risk may outweigh possible benefits (48). While there is no adequate data on the impact of corticosteroids in COVID-19 patients, current guidelines recommend against their use (49).

\section{Management of Complications}

Besides mentioned efforts in decreasing viral infectivity and controlling inflammatory response, current management of COVID-19 focuses on managing respiratory, cardiovascular and thrombotic complications in critically ill patients. Importantly, organ protective measures that may be taken before the overt development of organ dysfunction may decrease the high rates of organ dysfunction, namely renal damage and its detrimental effect on outcome.

In this context, the widely used renin-angiotensin-aldosterone system (RAAS) blocking agents require specific attention. ACE2, the cellular receptor used by SARS-CoV-2, is an enzyme that converts angiotensin-II into angiotensin 1-7, which has an opposing role to angiotensin-II and its inflammatory effects (50). Angiotensin 1-7 have vasodilator and anti-inflammatory effects through interaction with the Mas receptor (51). Previous studies showed that ACE2 knockout mice were more severely affected by acid-induced, endotoxin-induced and sepsis-induced ARDS compared with wild type mice. The increased severity of ARDS was associated with increased vascular permeability, lung edema and neutrophil infiltration. Likewise, administration of recombinant ACE2 protein improved the symptoms of lung injury in both ACE2 knockout and wild type mice, confirming the protective role of ACE2 in lung injury (51). Similarly, ACE2 has renoprotective role in various kidney diseases, including acute kidney injury (52, 53), possibly via the vasodilatory, anti-inflammatory and blood pressure lowering effects of angiotensin 1-7.

RAAS blockade using ACE inhibitors, angiotensin receptor blockers (ARBs) or mineralocorticoid receptor blockers increased ACE2 expression and activity in rats (54-56). Similarly, increased plasma angiotensin 1-7 level were observed in patients chronically treated with ACE inhibitors (57), an effect that was 
not seen immediately after the initiation of ACE inhibitors $(55,58)$. If RAAS blockade increases ACE2 receptor number and activity, the impact of ACEI/ ARBs on COVID-19 may be of importance. The activity of ACE2 hypothetically ameliorates inflammation and vasoconstriction-induced hypoxia in the lungs; on the other hand, it potentially increases viral entry points. According to existing data, the population at risk for severe COVID-19 includes patients with chronic underlying diseases (such as hypertension and diabetes) (13), who are usually on ACE/ARBs. Thus, the effects of ACEI/ARB on the disease course of COVID-19 are a critical question that waits to be addressed with randomized clinical trials. However some preliminary data already present regarding RAS and COVID-19 Mancia et al. performed a population-based case-control study in 6272 COVID-19 infected patients to explore RAS Blockers and the Risk of COVID-19. The have shown that use of ARBs or ACE inhibitors did not show any association with COVID-19 among case patients overall (adjusted odds ratio, $0.95[95 \%$ confidence interval $\{\mathrm{Cl}\}, 0.86$ to 1.05] for ARBs and 0.96 [95\% Cl, 0.87 to 1.07] for ACE inhibitors) or among patients who had a severe or fatal course of the disease (adjusted odds ratio, 0.83 [95\% Cl, 0.63 to 1.10$]$ for ARBs and 0.91 [95\% Cl, 0.69 to 1.21] for ACE inhibitors), and no association between these variables was found according to sex. Authors concluded that there was no evidence that ACE inhibitors or ARBs and the risk of COVID-19 (59). Reynolds et al. in an observational study, investigated the relationship between RAS inhibitors and risk of COVID-19. Among 12,594 patients who were tested for COVID-19, a total of 5894 (46.8\%) were positive; 1002 of these patients $(17.0 \%)$ had severe illness. A history of hypertension was present in 4357 patients (34.6\%), among whom $2573(59.1 \%)$ had a positive test; 634 of these patients $(24.6 \%)$ had severe illness. There was no association between any single medication class including RAS inhibitors and an increased likelihood of a positive test. None of the medications examined was associated with a increase in the risk of severe illness among patients who tested positive. Thus authors did not demonstrate any relationship between RAS inhibitor use, COVID-19 positivity and severity (60). These studies are observational studies. Fortunately, there are also numerous ongoing clinical trials are investigating possible therapeutic effect of ARBs for COVID-19 in patients requiring and not requiring hospitalization (clinical- trials.gov NCT04335123, NCT04312009, NCT04311177, NCT04343001, NCT04345406, NCT04355429), while other trials are investigating the outcomes of stopping or maintaining ACEI/ARBs or switching to alternative medications in patients with hypertension (clinicaltrials.gov NCT04364893, NCT04330300, NCT04330300, NCT04329195, NCT04338009). One prospective cohort will demonstrate the prognosis of COVID-19 in patient using ACEI/ARBs (clinicaltrials.gov NCT04357535). While the effects of RAAS blockage on the clinical course of COVID-19 are not yet known, discontinuation of ACEI/ARB in susceptible patient population is known to exacerbate co morbid cardiovascular and kidney disease and lead to increased morbidity and mortality $(55,61)$. Current guidelines recommend the continuation of these agents during COVID-19 unless discontinuation is indicated for other reasons (hypotension, AKI) (62).

The major reason for death in COVID-19 is hypoxemic respiratory failure. The role of hypoxemia in renal outcomes in COVID-19 is not known. Under normal conditions, kidneys receive $20 \%$ of the cardiac output. Despite this high amount, they are susceptible to ischemic insults. This is thought to depend on uneven distribution of blood flow between medulla and cortex. Indeed, the medulla has high energy consumption due to the $\mathrm{Na} / \mathrm{K} / 2 \mathrm{Cl}$ pump but relatively low blood supply under basal conditions, which renders the medulla relatively hypoxic. On the other hand, the cortex is well perfused. Nevertheless, during ischemia, there may be re-distribution of blood flow from cortex to medulla. This seems beneficial at early stages but if the primary insult continues, these adaptations become mal-adaptive and both cortex and medulla become hypoxic $(63,64)$. Indeed, the histopathologic examination of COVID19 non-survivors showed findings of ATN, implying ischemic ATN due to hypoxia may be a significant contributor to kidney function impairment.

COVID-19 causing kidney hypoxemia is a hypothetical concern. Thus, ameliorating hypoxia may be of value. Indeed, a recent case report showed that in an elderly COVID-19 infected patient with hypoxemia, anemia and tachycardia, a 7-day course of recombinant human Erythropoietin (rhEPO) was associated to improved symptoms and hemoglobin levels. The authors hypothesized that rhEPO could attenuate ARDS via multiple mechanisms including cytokine 
modulation, anti-apoptotic effects, leukocyte release from bone marrow and iron redistribution (65). However, as rhEPO favors thrombotic and COVID-19 may be associated with increased thrombosis risk, we should wait for the results of controlled studies before using rhEPO in COVID-19 patients.

Another novel class of drugs to treat anemia is hypoxia-inducible factor-1 (HIF-1) stabilizers. These drugs hypothetically reverse hypoxia (66) but no studies are performed till now. Another novel drug group namely SGLT2 inhibitors may also be beneficial in COVID19 and ongoing randomized clinical trial will be comparing dapagliflozin versus placebo in patients with mild-moderate COVID-19 for its association with disease progression, complications and allcause mortality (clinicaltrials.gov NCT04350593).

During the COVID-19 pandemic, exceedingly simple but equally important for renoprotection is the prudent use of non-steroidal anti-inflammatory drugs (NSAIDs) in all patients due to their detrimental effects on renal perfusion, especially when there is decreased intravascular volume. To avoid unnecessary renal compromise, acetaminophen is the antipyretic of choice for all patients and NSAIDs should be used in the minimum effective dose only if needed.

\section{Future Perspective}

As of today, worldwide lockdown measures and social distancing rules coupled with the hard work and devotion of health care professionals seem to be decreasing the daily number of new COVID-19 cases and deaths (67), which are still significantly high. Unfortunately, there is a growing concern for a second wave of infection among experts (68). While much is unknown, the current experience and current data should be used to develop future strategies.

According to the available data, the presence and severity of AKI is a strong predictor of outcome and may be used for patient stratification to better allocate medical resources. More frequent measurements of serum creatinine and urinalysis should be routinely performed to detect kidney injury early in the course.

During COVID-19 patient overload, medical centers faced an impending shortage of kidney replacement therapy, as reported from major hospitals in New York, the epicenter of COVID-19 in the USA (12).
Besides the high incidence of AKI in COVID-19 patients, personnel trained in renal replacement therapy were affected by COVID-19 and many were quarantined, contributing to a shortage of renal replacement therapy availability (12). Under those circumstances, it may be crucial to allocate the limited resources and prepare for a shortage in the face of upcoming peaks (69).

In addition to ongoing clinical trials and the search for effective treatment, more prospective and retrospective data analysis is needed. Careful assessment of populations at risk for developing COVID-19induced $\mathrm{AKI}$ is essential for setting up preventive measures. Furthermore, the association of CKD and COVID-19 severity should be assessed. The largest COVID-19 case series, published by the Chinese Center for Disease Control and Prevention included 44672 confirmed cases and showed an overall mortality rate of $2.3 \%$, which was much higher for patients with co-morbidities including cardiovascular disease $(10.5 \%)$, diabetes $(7.3 \%)$, chronic respiratory disease $(6.3 \%)$, high blood pressure $(6 \%)$ and cancer (5.6\%) (2). Whereas CKD was not listed among the co morbidities, it is known to be a key risk factor for $\mathrm{AKI}$ and, additionally, the mentioned co morbidities are very common in patients with CKD. Data is needed on the outcome of COVID-19 in CKD patients, as well as the safety and benefits of common pharmacologic agents used by these populations during COVID-19 infection.

\section{REFERENCES}

1. European Centre for Disease Prevention and Control (ECDC). Control ECfDPa. Situation update worldwide. Available from: https://www.ecdc.europa.eu/en/geographical-distribution-2019-ncov-cases\#: : text=ECDC\%20switched\%20to\% 20a\% 20weekly, aggregated\%20by\%20week\%20every\%20Thursday.2020.

2. Team TNCPERE. The epidemiological characteristics of an outbreak of 2019 novel coronavirus diseases (COVID-19) China, 2020. China CDC Weekly 2020; 2(8): 113-22.

3. Park SE. Epidemiology, virology, and clinical features of severe acute respiratory syndrome -coronavirus-2 (SARSCoV-2; Coronavirus Disease-19). Clin Exp Pediatr 2020; 63: 119-24

4. Li Y, Hu Y, Yu J, Ma T. Retrospective analysis of laboratory testing in 54 patients with severe- or critical-type 2019 novel coronavirus pneumonia. Nature 2020; 100: 794800 . 
5. Aggarwal S, Garcia-Telles N, Aggarwal G, Lavie C, Lippi G, Henry BM. Clinical features, laboratory characteristics, and outcomes of patients hospitalized with coronavirus disease 2019 (COVID-19): Early report from the United States. Diagnosis (Berlin, Germany) 2020; 7: 91-6.

6. Zhu J, Ji P, Pang J, Zhong Z, Li H, He C, et al. Clinical characteristics of 3,062 COVID-19 patients: a meta-analysis. J Med Virol 2020; 92(10): 1902-14.

7. Cheng $Y$, Luo $R$, Wang $K$, Zhang $M$, Wang $Z$, Dong $L$, et al. Kidney disease is associated with in-hospital death of patients with COVID-19. Kidney Int 2020; 97: 829-38.

8. Pei G, Zhang Z, Peng J, Liu L, Zhang C, Yu C, et al. Renal involvement and early prognosis in patients with COVID19 pneumonia. J Am Soc Nephrol 2020; 31(6): 1157-65.

9. Diao B, Feng Z, Wang C, Wang H, Liu L, Wang C, et al. Human Kidney is a target for novel severe acute respiratory syndrome coronavirus 2 (SARS-CoV-2) Infection 2020.

10. Yang $X, Y u Y, X u$ J, Shu H, Xia J, Liu H, et al. Clinical course and outcomes of critically ill patients with SARS-CoV-2 pneumonia in Wuhan, China: a single-centered, retrospective, observational study. The Lancet Respir Med 2020; 8(5): 475-81.

11. Huang C, Wang Y, Li X, Ren L, Zhao J, Hu Y, et al. Clinical features of patients infected with 2019 novel coronavirus in Wuhan, China. Lancet (London, England) 2020; 395: 497-506.

12. Goldfarb DS, Benstein JA, Zhdanova O, Hammer E, Block CA, Caplin NJ, et al. Impending shortages of kidney replacement therapy for COVID-19 patients. CJASN 2020; 15(6): 880-2.

13. Zhou F, Yu T, Du R, Fan G, Liu Y, Liu Z, et al. Clinical course and risk factors for mortality of adult inpatients with COVID-19 in Wuhan, China: a retrospective cohort study. Lancet (London, England) 2020; 395: 1054-62.

14. Chen $T$, Wu D, Chen $H$, Yan W, Yang D, Chen $G$, et al. Clinical characteristics of 113 deceased patients with coronavirus disease 2019: retrospective study. BMJ 2020; 368: $m 1091$.

15. Li Z, Wu M, Guo J, Yao J, Liao X, Song S, et al. Caution on kidney dysfunctions of 2019-nCoV Patients. 2020.

16. Wang D, Yin Y, Hu C, Liu X, Zhang X, Zhou S, et al. Clinical course and outcome of 107 patients infected with the novel coronavirus, SARS-CoV-2, discharged from two hospitals in Wuhan, China. Crit Care 2020; 24: 188.

17. Shi S, Qin M, Shen B, Cai Y, Liu T, Yang F, et al. Association of cardiac injury with mortality in hospitalized patients with COVID-19 in Wuhan, China. JAMA Cardiol 2020; 5(7): 802-10.

18. Han SS, Ahn SY, Ryu J, Baek SH, Chin HI, Na KY, et al. Proteinuria and hematuria are associated with acute kidney injury and mortality in critically ill patients: a retrospective observational study. BMC Nephrol 2014; 15: 93.
19. Su H, Yang M, Wan C, Yi LX, Tang F, Zhu HY, et al. Renal histopathological analysis of 26 postmortem findings of patients with COVID-19 in China. Kidney Int 2020; 98(1): 219-27.

20. Moeinzadeh F, Dezfouli M, Naimi A, Shahidi S, Moradi H. Newly diagnosed glomerulonephritis during COVID-19 infection undergoing immunosuppression therapy, a case report. Iran J Kidney Dis 2020; 14: 239-42.

21. Peleg Y, Kudose S, D'Agati V, Siddall E, Ahmad S, Kisselev $S$, et al. Acute kidney injury due to collapsing glomerulopathy following COVID-19 infection. Kidney Int Rep 2020; 5(6): $940-5$

22. Sanders JM, Monogue ML, Jodlowski TZ, Cutrell JB. Pharmacologic treatments for coronavirus disease 2019 (COVID-19): a review. JAMA 2020; 323(18): 1824-36.

23. Chen Y, Liu Q, Guo D. Emerging coronaviruses: Genome structure, replication, and pathogenesis. I Med Virol 2020; 92: 418-23.

24. ACE2 angiotensin I converting enzyme 2 [Homo sapiens (human)] Gene ID: 59272. NCBI 2020.

25. Kobayashi S, Venkatachalam MA. Differential effects of calorie restriction on glomeruli and tubules of the remnant kidney. 1992; 42: 710-7.

26. Pan X-W, Xu D, Zhang H, Zhou W, Wang L-H, Cui X-G. Identification of a potential mechanism of acute kidney injury during the COVID-19 outbreak: a study based on single-cell transcriptome analysis. Intensive Care Med 2020: 1-3.

27. Chousterman BG, Swirski FK, Weber GF. Cytokine storm and sepsis disease pathogenesis. Semin Immunopathol 2017; 39: 517-28.

28. Jose RJ, Manuel A. COVID-19 cytokine storm: the interplay between inflammation and coagulation. Lancet Respir Med 2020; 8(6): e46-e7.

29. Konig MF, Powell MA, Staedtke V, Bai RY, Thomas DL, Fischer NM, et al. Preventing cytokine storm syndrome in COVID-19 using alpha-1 adrenergic receptor antagonists. J Clin Invest 2020; 130: 3345-7.

30. Ronco C, Reis T. Kidney involvement in COVID-19 and rationale for extracorporeal therapies. Nat Rev Nephrol 2020; 16: 308-10.

31. Larsen CP, Bourne TD, Wilson JD, Saqqa O, Sharshir MdA. Collapsing glomerulopathy in a patient with coronavirus disease 2019 (COVID-19). Nephrol Rounds 2020; 5(6): 935-9.

32. Nicholas Cossey L, Larsen CP, Liapis H. Collapsing glomerulopathy: a 30-year perspective and single, large center experience. Clin Kidney J 2017; 10: 443-9.

33. Hinton RDM. Remdesivir EUA letter of authorization. Food and Drug Administration 22.10.2020. 
34. Barlow A, Landolf KM, Barlow B, Yeung SYA, Heavner IJ, Claassen $C W$, et al. Review of emerging pharmacotherapy for the treatment of coronavirus disease 2019. Pharmacotherapy 2020; 40: 416-37.

35. Tobaiqy M, Qashqary M, Al-Dahery S, Mujallad A, Hershan AA, Kamal MA, et al. Therapeutic management of COVID-19 patients: a systematic review. Infect Prev Pract 2020; 2(3): 100061.

36. Cao B, Wang Y, Wen D, Liu W, Wang J, Fan G, et al. A trial of Lopinavir-Ritonavir in adults hospitalized with severe COVID-19. N England J Med 2020; 382(19): 1787-99.

37. Gao J, Tian Z, Yang X. Breakthrough: Chloroquine phosphate has shown apparent efficacy in treatment of COVID-19 associated pneumonia in clinical studies. Biosci Trends 2020; 14: 72-3.

38. Gautret P, Lagier JC, Parola P, Hoang VT, Meddeb L, Mailhe $M$, et al. Hydroxychloroquine and azithromycin as a treatment of COVID-19: results of an open-label non-randomized clinical trial. Int J Antimicrob Agents 2020; 56(1): 105949 .

39. Borba MGS, Val FFA, Sampaio VS, Alexandre MAA, Melo GC, Brito M,et al. Effect of high vs low doses of chloroquine diphosphate as adjunctive therapy for patients hospitalized with severe acute respiratory syndrome coronavirus 2 (SARS-CoV-2) infection: a randomized clinical trial. JAMA 2020; 3: e208857.

40. Jun C, Liu D, Liu L, Liu P, Qingnian X, Xia L, et al. A pilot study of hydroxychloroquine in treatment of patients with common coronavirus disease-19 (COVID-19). Zhejiang Da Xue Xue Bao Yi Xue Ban 2020; 49(2): 215-9.

41. Monteil V, Kwon H, Prado P, Hagelkruys A, Wimmer RA, Stahl $M$, et al. Inhibition of SARS-CoV-2 infections in engineered human tissues using clinical-grade soluble human ACE2. Cell 2020; 181(4): 905-13.

42. Khan A, Benthin C, Zeno B, Albertson TE, Boyd J, Christie $J D$, et al. A pilot clinical trial of recombinant human angiotensin-converting enzyme 2 in acute respiratory distress syndrome. Crit Care (London, England) 2017; 21: 234.

43. Zhang H, Baker A. Recombinant human ACE2: acing out angiotensin II in ARDS therapy. Crit Care (London, England) 2017; 21: 305.

44. Tanaka T, Narazaki M, Kishimoto T. Immunotherapeutic implications of IL-6 blockade for cytokine storm. 2016; 8: 959-70.

45. Alzghari SK, Acuna VS. Supportive treatment with Tocilizumab for COVID-19: A systematic review. I Clin Virol 2020; 127: 104380.

46. Xu X, Han M, Li T, Sun W, Wang D, Fu B, et al. Effective treatment of severe COVID-19 patients with tocilizumab. Proc Natl Acad Sci USA 2020; 117(20): 10970-5.

47. Luo P, Liu Y, Qiu L, Liu X, Liu D, Li J. Tocilizumab treatment in COVID-19: A single center experience. I Med Virol 2020; 92(7): 814-8.
48. Russell CD, Millar JE, Baillie JK. Clinical evidence does not support corticosteroid treatment for 2019-nCoV lung injury. Lancet (London, England) 2020; 395: 473-5.

49. Infectious Diseases Society of America (IDSA). Infectious Diseases Society of America Guidelines on the Treatment and Management of Patients with COVID-19. IDSA 4/11/2020. Available from: https://www.idsociety.org/ practice-guideline/covid-19-guideline-treatment-andmanagement/

50. Sanz $A B$, Ramos $A M$, Soler MJ, Sanchez-Nino $M D$, Fernandez-Fernandez B, Perez-Gomez MV, et al. Advances in understanding the role of angiotensin-regulated proteins in kidney diseases. Expert Rev Proteomics 2019; 16: 77-92.

51. Imai Y, Kuba K, Ohto-Nakanishi T, Penninger IM. Angiotensin-converting enzyme 2 (ACE2) in disease pathogenesis. Circ J 2010; 74: 405-10.

52. Soler MJ, Wysocki J, Batlle D. ACE2 alterations in kidney disease. Nephrol Dial Transplant 2013; 28: 2687-97.

53. Mizuiri S, Ohashi Y. ACE and ACE2 in kidney disease. World I Nephrol 2015; 4: 74-82.

54. Ferrario CM, Jessup J, Gallagher PE, Averill DB, Brosnihan $K B$, Ann Tallant E,et al. Effects of renin-angiotensin system blockade on renal angiotensin-(1-7) forming enzymes and receptors. Kidney Int 2005; 68: 2189-96.

55. Buckley LF, Cheng JWM, Desai A. Cardiovascular Pharmacology in the time of COVID-19: A focus on angiotensin converting enzyme 2. J Cardiovasc Pharmacol 2020; 75: 526-9.

56. Karram T, Abbasi A, Keidar S, Golomb E, Hochberg I, Winaver J, et al. Effects of spironolactone and eprosartan on cardiac remodeling and angiotensin-converting enzyme isoforms in rats with experimental heart failure. Am J Heart Circ Physiol 2005; 289: H1351-8.

57. Luque M, Martin P, Martell N, Fernandez C, Brosnihan KB, Ferrario CM. Effects of captopril related to increased levels of prostacyclin and angiotensin-(1-7) in essential hypertension. J Hypertense 1996; 14: 799-805.

58. Campbell DJ, Zeitz CJ, Esler MD, Horowitz JD. Evidence against a major role for angiotensin converting enzyme-related carboxypeptidase (ACE2) in angiotensin peptide metabolism in the human coronary circulation. I Hypertense 2004; 22: 1971-6.

59. Mancia G, Rea F, Ludergnani M, Apolone G, Corrao G. Renin-angiotensin-aldosterone system blockers and the risk of COVID-19. N Engl J Med 2020; 382(25): 2431-40.

60. Reynolds HR, Adhikari S, Pulgarin C, Troxel AB, Iturrate $E$, Johnson $S B$, et al. Renin-angiotensin-aldosterone system inhibitors and risk of COVID-19. N Engl J Med 2020; 382(25): 2441-8.

61. Qiao Y, Shin II, Chen TK, Inker LA, Coresh J, Alexander GC, et al. Association between renin-angiotensin system blockade discontinuation and all-cause mortality among persons with low estimated glomerular filtration rate. JAMA Intern Med 2020; 180(5): 718-26. 
62. Blockers PSotECoHoA-laAR.

63. Ray SC, Mason J, O'Connor PM. Ischemic renal injury: can renal anatomy and associated vascular congestion explain why the medulla and not the cortex is where the trouble starts? Semin Nephrol 2019; 39: 520-9.

64. Gloviczki ML, Saad A, Textor SC. Blood oxygen level-dependent (BOLD) MRI analysis in atherosclerotic renal artery stenosis. Curr Opin Nephrol 2013; 22: 519-24.

65. Hadadi A, Mortezazadeh M, Kolahdouzan K, Alavian G. Does recombinant human Erythropoietin administration in critically ill COVID-19 patients have miraculous therapeutic effects? I Med Virol 2020; 92(7): 915-8.
66. Afsar B, Kanbay M, Afsar Elsurer R. Hypoxia inducible factor-1 protects against COVID-19: A hypothesis. Med Hypotheses 2020; 143: 109857.

67. Centers for Disease Control and Prevention (CDC). Provisional death counts for coronavirus disease (COVID19). 2020. Available from: https://www.cdc.gov/nchs/ nvss/vsrr/covid19/index.htm

68. Xu S, Li Y. Beware of the second wave of COVID-19. Lancet (London, England) 2020; 395: 1321-2.

69. Burgner A, Ikizler TA, Dwyer JP. COVID-19 and the inpatient dialysis unit. managing resources during contingency planning pre-crisis. Clin J Am Soc Nephrol 2020; 15(5): 720-2. 